\title{
PREDICTING THE INFLUENCE OF INTERACTIVE MARKETING COMMUNICATION TOOLS ON BRAND RESONANCE TO PURCHASE ROYAL ENFIELD BIKE
}

\author{
Dr. A. Praveen Kumar \\ Assistant Professor - Faculty of Business Administration \\ SS Arts and Science College, Bommayapalayam, Villupuram, India.

\section{Dr. J. Tamilselvi} \\ Associate Professor-Faculty of Business Administration, \\ Annamalai University, Chidambaram, India \\ Dr. R. Arulmoli \\ Professor-Faculty of Medicine, \\ AIMST University, Kedah, Malaysia.
}

\begin{abstract}
Purpose of the study: The aim of this study is to predict the effect of interactive marketing communication tools (social networking, email marketing, blogs and mobile marketing) on brand resonance in purchasing Royal Enfield bike in Puducherry city, India.

Methodology: The primary data was collected by using structured questionnaire distributed to 354 Royal Enfield bike owners in Puducherry city. The data was analyzed by reliability and validity analysis before hypothesis testing assessed.

Result: The results indicate that all the four interactive marketing communication tools play a positive significant influence to attain brand resonance on Royal Enfield bike owners to purchase the bike.
\end{abstract}

Applications of this study: The study will be helpful for the manufacturers and the showroom managers to decide the application of specific interactive marketing tools to build stronger resonance from the consumers to distinguish from their competitors.

Novelty/Originality of this study: The study will benefit the marketing practitioners and manufacturers to understand the application of specific interactive marketing communication tools to build brand resonance to attract the customers. 
Predicting the Influence of Interactive Marketing Communication Tools on Brand Resonance to Purchase Royal Enfield Bike

Key words: Interactive Marketing Communication tools, Brand resonance, Royal Enfield bike, India

Cite this Article: A. Praveen Kumar, J. Tamilselvi and R. Arulmoli, Predicting the Influence of Interactive Marketing Communication Tools on Brand Resonance to Purchase Royal Enfield Bike, International Journal of Management, 11(12), 2020, pp 1394-1402.

http://iaeme.com/Home/issue/IJM?Volume=11\&Issue=12

\section{INTRODUCTION}

Achieving brand resonance is an important factor for every organization to sustain in the competitive environment. Brand resonance is a psychological bond between the consumer and the brand. The marketing managers are struggling in many ways to attain brand resonance with the consumers. Hence, they need efficient interactive marketing communication tools (IMC) to reach the consumers. Without achieving brand resonance, consumers will switch to other brands or services which results in loss of valuable consumers and loss in business. To achieve this, the marketing managers use various interactive communication tools to enhance brand visibility and resonance.

In the present study, Royal Enfield bike is taken into consideration because it was established in India in 1955 and having trusted name for the past 60 years. Most of the bike owners in India prefer this bike because they think it is their pride to ride and own the bike. The Royal Enfield bike has official brand community and the active engagement loyalist number increases every year. In India, Rider's mania is officially arranged and thousands of loyalists actively participate in this program every year (Rishad Saam Mehta 2019).

(Kotler andKeller 2012),recognize the rising role of digital media application in marketing. They term it interactive marketing in which quick, easy and low-cost conversation is possible between the firm and the potential customers.

Recently, it is observed that the interactive marketing plays a major rolein effective marketing communication among practitioners especially in transmitting the information from the organization, about their products and services. It is documented that large number of companies have benefited from the usage of interactive marketing tools for the effective communication to retain their valuable consumers in the changing marketing environment. According to (Keller,K.L.2009), brand resonance pyramid helps to track how interactive marketing communication can create intense loyalty relationship that affects brand resonance pyramid. Although interactive marketing communication can play important role but must be used uniquely in complicated marketing environment.

In one study conducted by(Keller,K.L.2009),concludes that the organization should choose the appropriate interactive marketing communication tool which is most suitable and cost effective in satisfying sales target and right communication. Hence each interactive marketing communication tool must be carefully evaluated according to its ability to build brand resonance and motivate sales. However interactive marketing communication will affect more than one dimension of brand resonance factor, most options are having greater impact in certain areas.

\section{LITERATURE REVIEW}

\subsection{Interactive Marketing Communication}

The end of twentieth century is a boon for the use of interactive technologies, as most users are the Gen Y people, technologically multi taskers who are interested to engage in loaded interactive experience over the social media and mobile platform. With the tremendous 
growth of internet, marketing practioners and companies scrambled to build their presence in cyberspace. The various approach to reach the consumers is different for each company.(Kotler P.T and Armstrong 2011),recognizes that interactive marketing means the product quality depends heavily on the interaction between buyer and seller during service encounter.

(Goran Vlasic 2007), in his study, analyzed the consumer's attitude towards two concepts. The study was carried out by online survey of respondents of internet users in Croatia. The result indicates that consumers have a more positive influence attitude toward interactive marketing communication than toward one-way communication. Also it was found that the consumers do need interactive communication options, but they are more oriented about personalization factors.

A study by (Dushyenthan 2012), revealed that interactive marketing communication has positive impact on customer satisfaction. Relationship commitment factor and trust in the interactive marketing contribute high impact to customer satisfaction. And customer satisfaction has no positive influence on personalizing services and complaint handling factors in the interactive marketing tools.

In another study it was found that the interactive advertising tools has opened so many economic prospects and greater advancements for marketers and advertise companies and even researchers. But only fewer studies can be found delving on the important role of interactive advertising tools in managing and developing brand equity pyramid.(Salem Mohamed, S.,2014).

Studies also revealed that professional organization in direct and interactive marketing and integrated marketing communications have worked together to reach a profitable balance between science and art as well as creative techniques to reach the consumers. At its best, the interactive marketing communication explore the future world of creativity with the unique technique of measured response.(Adriana Csikósová., 2014).

\subsection{Brand Resonance}

Brand resonance is defined as the nature of relationship and the extent to which consumers feel how they are synchronized to their favourite brand. In other words, resonance is expressed in terms of intensity or the depth of psychological bond as well as the level of loyalty and active engagement the consumer having with their brand.(Keller, K. L. 1993).

Interactive marketing communication has a significant role in attaining brand resonance. Various studies also documented that IMC tools influence brand resonance. In one study conducted by (Subhojit Chakraborty 2013), emphasize that social networking is a strong mechanism to resonate brands as it has positive potentialities of creating awareness, generating opinions, influencing customer behaviour and diffusing viral content to buy their product.

Another study reveals that the social networking communication was actively used during the Gezi Park events that took place in Turkey which is considered as most important one in Turkish history. The results revealed that the brand resonance of Starbucks increased rapidly after the events conducted by brand resonance. Also found out that the young social media users had apositive influence on Starbucks' brand resonance during the events.(EbruGökaliler 2016)

Social networking advertisements have significant positive effect on building brand equity to attain brand resonance. Moreover, this study (Jalal Hanaysha 2016), found that social networking advertisements have significant positive influence on all dimensions of brand equity pyramid. The author conclude that social networking advertisement is one of the key 
success factors for building and maintaining strong brand equity pyramid to attain brand resonance.

In another study it was investigated on how the interactivity of brand micro-blog entities influences brand resonance factor and customer purchase intention through brand micro-blog identification. The results revealed that customer oriented marketing interactive tools, have positive significant influence on brand micro-blog identification, which in turn has a positive significant influence on brand resonance. (Haichuan Zhao and Xian Cheng 2019).

Though number of studies were conducted on brand resonance, most of these studies were on social media communication only. But none of the studies were conducted to analyze the influence of interactive marketing communication tools to build brand resonance factors especially in two-wheeler segment in Indian context. Having identified this major research gap, the present study is carried out to analyze the factors that influence to build brand resonance through interactive marketing communication tools among two-wheeler segment in Puducherry city, India.

\subsection{Relationship between Interactive Marketing Communication and Brand Resonance}

Unquestionably, every aspect of brand resonance pyramid is positively impacted to interactive marketing communication as a brand building tool and its versatility. Interactive marketing communication is perhaps more useful in building brand resonance that enhances daily feedback opportunity because of two-way communication. (Keller,K.L.,2001).

The interactions by the use of interactive communication can strengthen brand attachment factor. Also, the use of blogs, mobile apps and other means help to build brand community among customers between the company and consumers.( Keller,K.L.,2009).

\section{H1: There is a positive and significant relationship between blogs and brand resonance}

\section{H2: There is a positive and significant relationship between mobile marketing and brand resonance}

Perhaps to build brand resonance where interactive marketing communications can have more impact with active engagement. Indeed, interactive marketing communication allows customer to learn and to teach other users about the brand, as well as explicit their commitment to brand and brand loyalty of others. In the study conducted by(Ya-Yun Cheng and Wei-Feng 2009)revealed that information search and social networking are the outcomes of customer brand engagement which leads to brand resonance. Further the study conducted by (Marko Merisavo and Mika Raulas2004) explored that regular e-mail marketing has positive effects on brand loyalty to attain brand resonance. They concluded that frequent contact with customers via e-mail helps to build brand loyalty thereby to build brand resonance.

H3: There is a positive and significant relationship between social networking and brand resonance.

H4: There is a positive and significant relationship between Emailmarketing and brand resonance. 


\section{RESEARCH METHODOLOGY}

This quantitative research was carried out to identify the interactive marketing communication tools which influence to build brand resonance to purchase Royal Enfield bike in Puducherry city, India.

\subsection{Pilot Study}

Convenience sampling method is opted for the collection of data and the sample size was 70.The standard deviation for this technique was 0.52 by using Cronbach's alpha(Keith S. Taber 2018).The sampling area was Puducherry city. For all the items selected in the questionnaire construction, the reliability was ranged from 0.78 to 0.98 as mentioned below.

Table 1

\begin{tabular}{|c|c|c|c|}
\hline S.No & Variables & Item & Reliability \\
\hline I & Demographic Profiles & 8 & ----- \\
\hline II & $\begin{array}{l}\text { Interactive marketing } \\
\text { communication }\end{array}$ & 6 & 0.90 \\
\hline III & Brand Resonance & 24 & 0.94 \\
\hline
\end{tabular}

\subsection{Population of the Study}

The population under this study was purposively taken into consideration of past two years' sales of Royal Enfield bike in Puducherry city totaling 3075.Two-year sales report of the Royal Enfield bike in the Puducherry city is given below.

Table 2

\begin{tabular}{|c|l|c|c|}
\hline S.No & \multicolumn{1}{|c|}{ Place of sale } & Year & Sales \\
\hline 1. & Royal Enfield Bike show room sales & 2017 to 2018 & 1805 \\
\hline 2. & in Puducherry city. & 2018 to 2019 & 1270 \\
\cline { 3 - 4 } \cline { 3 - 4 } & & Total & 3075 \\
\hline
\end{tabular}

\subsection{Sample size Determination and Selection}

Yamane (1967) formula was applied for sample size determination which provides simplified way to compute sample size.(Singh,Ajay S.,2014).

$\mathrm{N}=\mathrm{N} / 1+\mathrm{Ne}^{2}$

$$
\begin{gathered}
n=\frac{3075}{1+3075(.05)^{2}} \\
n=353.96 \\
n=354
\end{gathered}
$$

As per the result from the above formula 354 respondents were selected for data collection for this study.

\subsection{Questionnaire Construction}

The measurement scales of Interactive marketing communication were taken from past studies. Keller has identified 11 Interactive marketing tool options to reach the consumers effectively. In the current study the researcher has identified 4 tool options namely social networking, mobile marketing, blogs and email marketing, that the users of Royal Enfield 
bike are commonly experiencing. These 4 options are taken to measure the level of importance in a five-point scale. Brand Resonance scale stated above comprised of four dimensions namely, brand loyalty, brand attachment, brand community and active engagement adapted from Kevin lane Keller scale.(Keller, K. L. 2008)

\subsection{Method of data Analysis}

In the study the researcher has used both primary data and secondary data. Primary data was collected using a pilot tested questionnaire that consisted of 43 questions. The response for this study was collected using a Likert like scale of 1 to 5 from strongly disagree to strongly agree. Secondary data was collected from the Royal Enfield bike show room report and published research were also used for collecting data.

The questionnaire has been divided into three sections of A, B and C. Section A includes demographic information such as gender, age, education, income, occupation, residence and educational qualification. Section B consists of questions on independent variable interactive marketing communication tools like mobile marketing, social networking, blogs and email marketing. Lastly, section $\mathrm{C}$ contains the questions related to dependent variables of brand resonance which include brand loyalty, brand attachment, brand community and active engagement. Data was analyzed using SPSS software.

\section{ANALYSIS AND DISCUSSION}

Table 1 Influence of Mobile marketing, social networking, Email marketing and Blogs on Brand resonance

Table 3 Model summary

\begin{tabular}{|l|l|}
\hline \multicolumn{1}{|c|}{ Dependent Variable } & \multicolumn{1}{c|}{ Brand Resonance } \\
\hline Independent Variables & $\begin{array}{l}\text { Mobile marketing, Social networking, Email } \\
\text { Marketing and Blogs }\end{array}$ \\
\hline $\mathrm{R}$ & 0.754 \\
\hline $\mathrm{R}^{2}$ & 0.569 \\
\hline Adjusted $\mathrm{R}^{2}$ & 0.566 \\
\hline $\mathrm{F}$ - Value & 192.239 \\
\hline $\mathrm{P}$ - value & 0.001 \\
\hline
\end{tabular}

Source: primary data

The application of multiple regression shows that the model is fit, because the F-value is 192.239 and p-value is 0.001 . The result shows that the model is fit at one per cent level. From this above table it is found that the adjusted $\mathrm{R}^{2}$ value is 0.569 . This shows that the independent variables predict the dependent variable to the tune of 56.9 percent.

The mobile marketing obtained $\beta$ value 0.268 is validated by t-test. The result t-test value is statistically significant at $1 \%$ percent level, null hypothesis is rejected in favor of the alternative hypothesis and conclude that there is significant influence of mobile marketing on brand resonance. The E-mail marketing obtained $\beta$ value 0.202 is validated by t-test. The result t-test value is statistically significant at $1 \%$ percent level, null hypothesis is rejected in favor of the alternative hypothesis and conclude that there is significant influence of E-mail marketing on brand resonance. The social networking obtained $\beta$ value 0.296 is validated by t-test. The result t-test value is statistically significant at $1 \%$ percent level, null hypothesis is rejected in favor of the alternative hypothesis and conclude that there is significant influence of social networking on brand resonance. The blogs obtained $\beta$ value 0.290 is validated by ttest. The result t-test value is statistically significant at $1 \%$ percent level, null hypothesis is 
rejected in favor of the alternative hypothesis and conclude that there is significant influence of blogs on brand resonance.

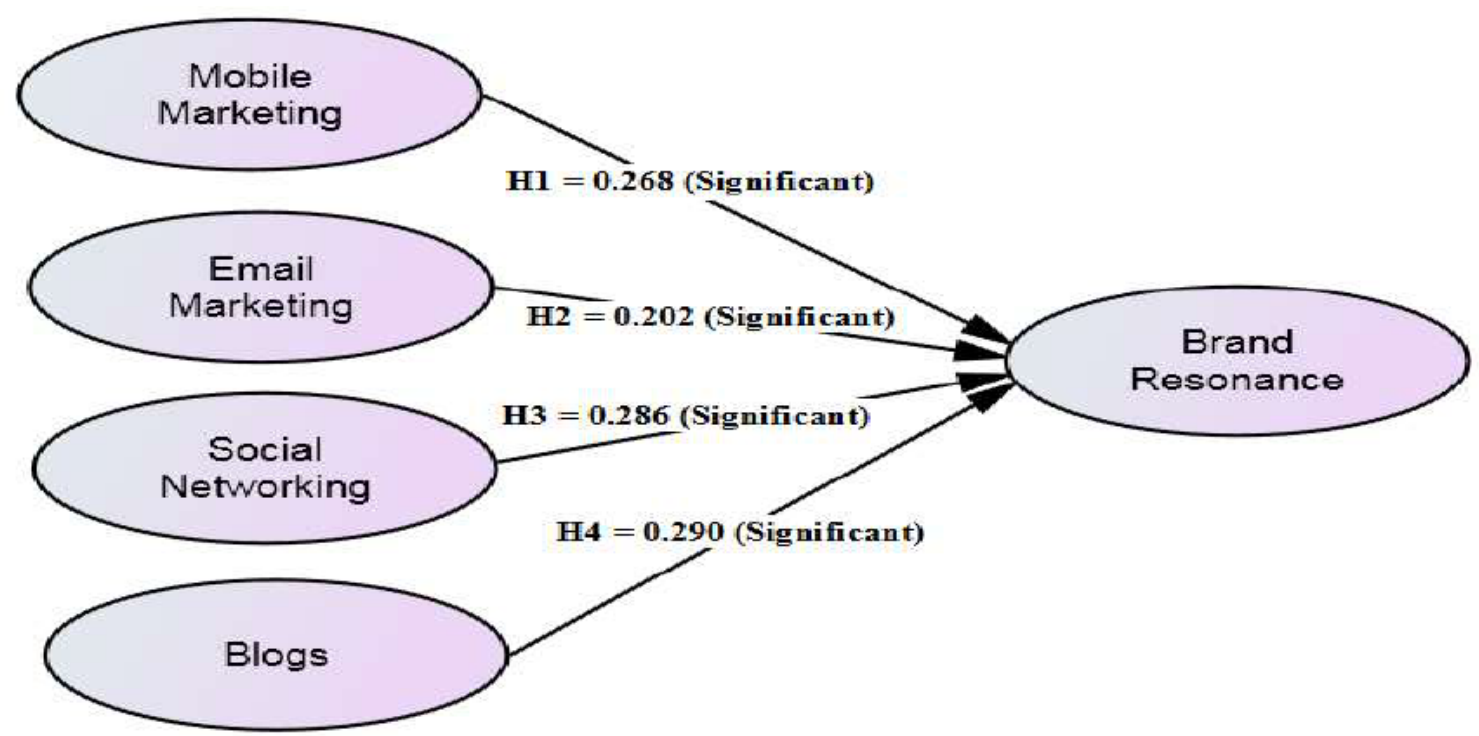

Figure 1

\section{CONCLUSION AND DISCUSSION}

The result of the study shows that all the four interactive marketing communication tools significantly affect the brand resonance to buy the Royal Enfield bike. Firstly, this study concludes that brand resonance factor has a positive relationship with the social networking communication in purchase of Royal Enfield bike. As stated by (Subhojit Chakraborty 2013)that social networking is indeed a strong mechanism when it comes to engaging customers and to achieve brand resonance. This suggest that Royal Enfield bike owners in Puducherry city are highly influenced by social networking media. Hence it is recommended that the company should advertise through the social networking media. Secondly, the result revealed that there is a significant relationship between brand resonance and email marketing and blogs. This finding is similar with the previous study conducted by (Haichuan Zhao and Xian Cheng 2019), which states that brand microblogs have positive effect on brand resonance. This infers that the show room managers should concentrate on sending promotional messages through the interactive marketing communication tools to reach consumers. Thirdly, this study reveals that there is a positive significant relationship between brand resonance factors and mobile marketing. Hence the show room managers should provide appealing advertisement in mobile marketing to create strong brand engagement about their products to consumers.

\section{LIMITATIONS AND STUDY FORWARD}

Understanding the interactive marketing communication tools from the above different perspectives will help manufacturers and marketers to implement more impactful communication options. But this study focused only four IMC tools on brand resonance factor in purchase of Royal Enfield bike. Further research can be done with various other IMC tools like widgets, microsites, display ads, interstitials etc., on brand resonance. This study focused only two-wheeler segment and hence further study should be carried out for other consumer products with full customer-based brand equity pyramid. 
Predicting the Influence of Interactive Marketing Communication Tools on Brand Resonance to Purchase Royal Enfield Bike

\section{REFERENCES}

[1] Adriana Csikósová (2014). Strategy in Direct and Interactive Marketing and Integrated Marketing Communications. Social and Behavioral Sciences Vol 116, pp1615 - 1619. https://doi.org/10.1016/j.sbspro.2014.01.444

[2] Dushyenthan (2012).Interactive marketing communication and its impact on customer satisfaction-The study of mobile communication service providers in Jaffna Srilanka. Global Journal of Management and Business Research Vol 12,issue-14.

[3] Ebru Gökaliler (2016).The Effects of Social Media Usage on Brand Resonance during and After the Gezi Park Protests in Turkey. Online Journal of Communication and Media Technologies. Volume: 6 - Issue-2.

[4] 4.Goran Vlasic (2007). Analysis of Consumers' Attitudes toward Interactivity and Relationship Personalization as Contemporary Developments in Interactive Marketing Communication. Journal of Marketing Research Vol 13,Issue -2,pp 109-129 https://doi.org/10.1080/13527260601070417

[5] Haichuan Zhao and Xian Cheng(2019). Do brand micro-blogs entities' interactivity enhance customer's brand resonance? Evidence from China. Asian Business \& management. https://doi.org/10.1057/s41291-019-00095-x

[6] Jalal Hanaysha (2016).The Importance of Social Media Advertisements in Enhancing Brand Equity: A Study on Fast Food Restaurant Industry in Malaysia. International Journal of Innovation, Management and Technology, Vol. 7, No. 27.

[7] Keith S. Taber (2018). The Use of Cronbach's Alpha When Developing and Reporting Research Instruments in Science Education. Research in Science Education Vol -48,PP1273-1296. Doi 10.1007/s11165-016-9602-2

[8] 8. Keller, K. L. (1993). Conceptualizing, Measuring and Managing Customer Based Brand $\begin{array}{llllll}\text { Equity. Journal of } & \text { Marketing, } & \text { Vol. } & \text { 57(1), } & \text { pp }\end{array}$ https://doi.org/10.1177/002224299305700101

[9] Keller, K. L. (2008). Strategic Brand Management - Building, Measuring, and Managing Brand Equity. Third edition, Pearson Prentice Hall, New

[10] Jersey.https://tranbaothanh.files.wordpress.com/2016/09/strategic-brand-management-4thedition.pdf

[11] Keller, K.L.(2009). Building strong brands in a modern marketing communications environment. Journal of marketing communications, Vol 15,pp-139 155.https://doi.org/10.1080/13527260902757530

[12] Keller, K.L.(2001).Mastering the Marketing Communications Mix: Micro and Macro Perspectives on Integrated Marketing Communication Programs. Journal of Marketing management ,Vol 17,pp-819-847.https://doi.org/10.1362/026725701323366836

[13] Kotler, P. T. and Keller, K. L. (2012). Marketing Management. Prentice Hall, New Jersey

[14] Kotler P .Tand Gary Armstrong (2011) Principles of marketing .Prentice Hall, New Jersey

[15] Keller,K.L.(2012).Understanding the richness of brand relationships: Research dialogue on brands as intentional agentsJournal of Consumer Psychology, Vol 22,pp-186190.https://doi.org/10.1016/j.jcps.2011.11.011

[16] RishadSaamMehta(2019).A look at the just-concluded Rider Mania 2019 .The hindu.https://www.thehindu.com/life-and-style/motoring/a-look-at-the-just-concluded-ridermania-2019/article30096385.ece 
[17] Salem Mohamed S.(2014). The Role of Interactive Advertisements in Developing Consumer based Brand Equity: A Conceptual Discourse. Social and Behavioral Sciences Vol 155 ,pp 98 - 103.https://doi.org/10.1016/j.sbspro.2014.10.263

[18] Subhojit Chakraborty (2013).Using social networking as a mechanism to achieve brand resonance : An empirical study.. International Journal of Technical Research and Applications. Volume 1, Issue 1, PP. 01-04.

[19] Singh, Ajay .S(2014).Sampling techniques \& detremination of sample size in applied statistics research: An overview. International Journal of Economics, Commerce and Management. Vol. II, Issue 11. http://ijecm.co.uk/wpcontent/uploads/2014/11/21131.pdf

[20] Ya-Yun Cheng and Wei-Feng (2009). Linking relationship equity to brand resonance in a social networking brand community: Electronic Commerce Research and Applications Volume 35, May-June 2019, 100849. https://doi.org/10.1016/j.elerap.2019.100849

[21] Merisavo, M. and Raulas, M. (2004). The impact of e-mail marketing on brand loyalty: Journal of Product \& Brand Management, Vol. 13 No. 7, pp. 498-505. https://doi.org/10.1108/10610420410568435 